\title{
MSME Funding with Securities Crowdfunding in Indonesia and the People's Economic System
}

\author{
Nanin Koeswidi Astuti ${ }^{1}$, Suhariningsih ${ }^{2}$, Sukarmi $^{3}$, Siti Hamidah ${ }^{4}$ \\ \{nanin.koeswidi@uki.ac.id\} \\ Universitas Kristen Indonesia, Jakarta, Indonesia ${ }^{1}$, Universitas Brawijaya, Malang, Indonesia ${ }^{2}$, \\ Universitas Brawijaya, Malang, Indonesia ${ }^{3}$, Universitas Brawijaya, Malang, Indonesia ${ }^{4}$
}

\begin{abstract}
This paper analyses securities crowdfunding as a funding prospect for MSMEs in Indonesia. The concept of crowdfunding and its relation to the concept of a populist economic system regulated in the economic constitution. Normative research method with legislation and concept approach. The opportunity for SCF to assist capital for MSMEs and start-ups has fulfilled the mandate of the economic constitution but requires stricter supervision from the Financial Services Authority so that SCF related parties and the community can benefit from this SCF, such as opening up business opportunities, and of course the objectives of the economic system. citizenship will be achieved. POJK Number $57 / 2020$ as an SCF regulation aims to protect investors, provide access to capital, market efficiency, provide benefits, and create healthy business competition. Crowd funding is reviewed from Article 33 paragraph 1 of the 1945 Constitution that the economy is structured as a joint effort so that economic actors are not only limited to BUMN, private companies, and cooperatives, but also the community, legal entities, and business entities, so that the principle of kinship and togetherness can be realized.
\end{abstract}

Keywords: MSME funding, securities crowd funding, A system of economic society

\section{Introduction}

The Covid-19 pandemic has caused various business and financial sectors to experience a decline in turnover and income, this of course will lead to an unstable economy in the world and Indonesia in particular. The rate of economic growth in the first quarter (January-March) of 2020 was $2.97 \%$, slowing from $4.97 \%$ in the fourth quarter of 2019 . In the second quarter of 2020, Indonesia's economic growth rate was minus 5.32\%. The budget for handling Covid19 and National Economic Recovery (PEN) is set at Rp. 695.20 trillion by the Government which is allocated to six sectors, namely the health sector, the social protection sector for the lower middle class, the ministry/institution and local government sector, the MSME sector. worth, the corporate financing sector, and the incentive sector for the business world. The Government's program aims to enable business actors and MSMEs to continue to run their businesses and improve economic capacity during the pandemic so that they can contribute to the Indonesian economy. PEN funding sources come from the APBN, placement of funds, guarantees, state capital participation, and government investment [1].

The government is trying in various ways to obtain development funds, loan capital from abroad, and in particular to suppress domestic capital in order to reduce debt from abroad. One of the ways taken by the government is to take advantage of developments in information and technology, namely through crowdfunding or equity crowdfunding (ECF). In Indonesia, the 
development of ECF since the regulation released by the Financial Services Authority, namely POJK No. 37/1998 released in 2018 until 2020, there are only 111 'issuers' that use ECF as a tool to seek funding, with emissions of only around Rp. 50 billion. This growth is not in line with what was expected by the government because there are still many MSMEs that are not yet in the form of a corporate legal entity [2].

There are two activities of Securities crowdfunding, the first is the sale and purchase of shares, where the concept is similar to the concept of investing in the capital market, but the difference is that investors or investors provide capital to fund a business or business through the purchase of shares of the issuer through an organizer platform, while the issuer of shares is a legal entity as well as other business entities such as cooperatives, CV, Firms, Civil Partnerships, Trade Businesses, and others. The second activity is the sale and purchase of Sukuk or sharia securities in the form of certificates or proof of ownership that have the same value and represent an inseparable or undivided part (syuyu'), of the underlying asset [3]

Several studies on ECF have focused on the legal relationship in crowdfunding and the contractual principles that are demonstrated in it [4]. Research on the ECF legal framework for modes of financing in other countries already exists and the benefits of the need for an ECF to be regulated [5]. Legal protection for the development of the financial sector through technology that has been protected in Title III Job's Act [6]. Legal protection of small investors in practice in Germany [7]. However, related to the topic of SCF, the existing literature is still rarely studied, especially regarding whether crowdfunding is under the concept of a people's economy as regulated in the economic constitution.

The government's legal politics to maximize efforts to get fresh funds from the public, the OJK expanded the scope of crowdfunding or ECF which used to be only in the form of equity or shares into shares and also Sukuk or sharia-based debt securities, so it was called securities crowdfunding or SCF with the issuance of POJK No. 57/2020 seen from the point of view of the people's economy whether it is in line with the people's economy so that the policies taken by the government contain political democracy as well as economic democracy which is none other than the people's sovereignty in the economic field. The goal of a populist economic system is that people are free from poverty, ignorance, dependence, unfair treatment, environmental damage, and feelings of anxiety in looking at the future [8].

Policies in obtaining resources from the community by utilizing information technology can be an option to be free from loans from investors or foreign investors in financing MSMEs so that they can and can open new jobs so that the ideals of social justice as stated in the 5th principle of Pancasila can be achieved. materialized.

The structure of this article is as follows: In part 2 we will explain government policies, in particular how economic policies are to obtain resources outside the stock exchange. In section 3 we formulate Research Methods. Section 4 describes the results of the study. Section 5 concludes.

\section{Research Methods}

\subsection{Securities crowdfunding \\ Legal Basis}

In 2018 there were regulations regarding equity crowdfunding in Indonesia, but since December 2020 with the issuance of POJK Number 57/POJK.04/2020, POJK Number 37/POJK.04/2018 was revoked and declared invalid. The difference between POJK Number 
37/2018 and POJK Number 57/2020 is regarding the addition of the securities base and slight modifications to the timeline for the issuance of crowdfunding, namely into equity and debt. The definition of securities in POJK Number 57/2020 is securities, namely debt acknowledgments, commercial securities, shares, bonds, proof of debt, participation units in collective investment contracts, futures contracts on securities, and any derivatives of securities.

Security is a security of a financial instrument that can be exchanged and negotiated that has some type of monetary value that represents an ownership interest in a public company through shares, investor relations with government agencies or corporations represented by the bondholders of the agency or ownership rights represented by rights voice. Securities are categorized into two different types, namely equity and debt. However, there are some securities combining equity and debt.

Insecurities crowdfunding, there are two main activities, namely buying and selling shares and buying and selling debt securities. Share buying and selling activities are carried out by issuers holding Indonesian business licenses, whether in the form of legal entities or other business entities that issue Securities through Crowdfunding Services. An investor is a party who purchases Securities from an issuer through an SCF operating platform. While the sale and purchase of debt are carried out to finance activities or work that produce goods, services, and/or other benefits, both existing and future ones, including predetermined investment activities which will be the basis for the issuance of debt securities or Sukuk.

POJK Number 57/2020 can be said to expand the reach of laws and regulations on the capital market outside the stock exchange, as well as the sale and purchase of shares and debt securities which are offered publicly through information technology-based stock offerings through SCF organizers, with total funds raised through securities offerings. a maximum of 10 billion rupiahs in a maximum period of 12 months. The SCF organizer must be a limited liability company and a cooperative. While buying and selling in the form of debt securities or Sukuk must obtain supervision from the Sharia Supervisory Board. and has mechanisms and procedures for determining equity securities as sharia securities.

\subsection{Government Policy to Obtain Funding Outside the Stock Exchange}

The development of Information Technology influences the development of the financial services industry. Business actors take advantage of this opportunity to obtain funding through the capital market by organizing a Crowdfunding Service for Information Technology-based share offerings (Equity Crowdfunding) which aims to expand access to financing for small and medium enterprises (SMEs) and start-up companies.) to obtain funding through the Capital Market. To broaden the scope of the Issuer in Crowdfunding Services and expand the scope of Crowdfunding Services so that it can include offerings other than equity securities in the form of shares, it is necessary to replace POJK Number 37/POJK.04/2018. Securities Offering Through Information Technology-Based Crowdfunding Services hereinafter referred to as Securities Crowdfunding.

Business entities in the form of a company can be owned by Indonesian citizens (WNI) or Indonesian legal entities and or foreign citizens (WNA) and or foreign legal entities with maximum share ownership of a maximum of $49 \%$, with a minimum paid-up capital of IDR 2.5 billion at the time of applying. permission. Meanwhile, service cooperatives can become SCF providers, as well as own capital of at least Rp. 2.5 billion at the time of submitting a permit application where capital is principal savings, mandatory savings, reserve funds, and grants as referred to in the cooperative law. 
There is a limitation in raising funds by the issuer within a maximum period of 12 months, which is 10 billion IDR and it is prohibited to change the minimum amount of funds based on the agreement contained in the Crowdfunding Service operation agreement throughout the securities offering period. If this minimum amount is not met, the offer will be null and void and the Operator must return the funds and all benefits arising from the funds while in the escrow account proportionally to the Investor.

\subsection{Methods}

This study uses a doctrinal or normative juridical legal research methodology with a statutory approach and a conceptual approach. Normative legal research is a process to find a rule of law, legal principles, and legal doctrines in order to answer the legal issues faced. In this type of research, the law is often conceptualized as what is written in statutory regulations, or the law is conceptualized as a rule or norm which is a benchmark for human behavior that is considered appropriate. POJK Number 57/POJK.04/2020 as an SCF regulation is conceptualized as a set of rules issued by the state with orders to be implemented (das sollen).

\section{Results and Discussion}

Modern society in doing business has individual motives as in Max Weber's view, that modern society is a rational society, with high efficiency and productivity. The use of economic theory in the regulation of the rule of law, because the empirically proven theory is very useful in hypothesizing and testing market behavior and is the object of microeconomics [9].

The legal politics of MSMEs in Indonesia is based on Pancasila. So that MSME actors can develop and have competitiveness with other business actors who have a large capital. MSMEs need to be developed in economic liberalization because MSMEs are one of the pillars in economic development that are fostered and protected by the government and have the potential to compete in the global market and have resilience and independence in doing business. The government's legal politics in protecting MSMEs is reflected in Article 6 letter $\mathrm{g}$ of Law No. 9 of 1995 concerning Small Business Jo. Article 7 of Law No. 20 of 2008 concerning MSMEs. However, the regulation does not specify the form of regulations that must be issued to be able to regulate and implement protection for MSME [10].

Failure to protect related parties in the SCF will lead to an economic crisis in society which will affect economic stability. For example, the gap in the ease of getting information, MSMEs and startups that build their businesses are financed with capital from investors or investors, it may be dishonest whether the business is growing or has gone bankrupt, moreover, we know that in this SCF uses technological advances in providing information for the public who will buy shares offered on the platform of organizers such as Santara, Bizhare, the public buys shares with the help of an application called "Robo advisor" which has the function of an investment manager in the capital market. Speculation of MSME businesses and startups by taking advantage of the ignorance of the organizers and investors for their benefit is a moral hazard that can harm investors. Therefore, it is necessary to have regulations that apply the principle of transparency of financial information and a financial reporting system that is closely monitored by the OJK. 
Table 1. Pictures and Illustration

\begin{tabular}{|l|l|l|l|}
\hline & Capitalism & Market Socialism & Planned Socialism \\
\hline $\begin{array}{l}\text { Decision making } \\
\text { structure }\end{array}$ & $\begin{array}{l}\text { Primarily } \\
\text { decentralized }\end{array}$ & $\begin{array}{l}\text { Primarily } \\
\text { Decentralized }\end{array}$ & $\begin{array}{l}\text { Primarily } \\
\text { centralized }\end{array}$ \\
\hline $\begin{array}{l}\text { Mechanisms for } \\
\text { coordination }\end{array}$ & Primarily market & Primarily market & Primarily plan \\
\hline Property rights & $\begin{array}{l}\text { Primarily private } \\
\text { ownership }\end{array}$ & $\begin{array}{l}\text { State and or } \\
\text { collective ownership }\end{array}$ & Primarily state \\
\hline Incentives & Primarily material & Material and moral & Material and moral \\
\hline
\end{tabular}

Source: Paul R. Gregory and Robert C. Stuart, Comparative Economic System, Fourt Edition, Houghton Mifflin Company, Boston, page.24.

The form of a country's economic system affects the making of regulations, disclosure of information, property rights, and incentives obtained from business actors. The capitalist system is known for its entrepreneurial spirit, where there is courage in taking risks, competition, and the desire to try. The theory of contract law in the capitalist system began in the XI and XII centuries which gave birth to the principle of contract law pacta sun servanda, a binding promise as a law must be fulfilled by the parties who make it [11].

There is a reciprocal exchange of rights in contract law which Hobbes calls a contract, anyone can exchange their rights to another person either for money, services immediately or through promises of fulfillment at a later date to create a contract like this, something has to be exchanged and has been agreed beforehand as obligatory [12]. Adam Smith's free-market concept and Jeremy Bentham's concept of utilitarianism which rests on the principle of benefit for the greatest happiness for the greatest number of the people developed into a free market as a manifestation of economic democracy, where everyone has the same opportunity to express there will freely and rationally. the opportunity to participate and interact in the marketplace, where everyone will get what they want and provide what others need [13]. However, this concept ignores justice which is the main goal of the law.

The concept of a free market in the Indonesian constitution still requires state intervention as an economic regulatory authority and as a regulator to protect the freedom of the market itself and aims to create justice, order, and legal certainty for every market participant and as an effort to prevent market failures. This intervention is in the form of government legal politics in making the rule of law.

The regulations in the SCF in the Indonesian legal system aim to protect investors, provide access to capital for entrepreneurs who do not have large capital in developing their businesses, increase market efficiency by providing benefits to the parties in the SCF industry and create a competitive business. healthy. This includes providing legal protection and settlement related to the sale and purchase of securities and debt securities or SUKUK as agreed in the contract. The government through the OJK as a regulator makes regulations and also takes the necessary actions in the event of economic, social inequality, market failures. The market economy system is a just economic system as regulated in Article 33 paragraph 4 of the 1945 Constitution, namely the national economy is organized using minimal resources to achieve the greatest prosperity that can be enjoyed equally by all people.

The concept of crowdfunding when viewed from article 33 paragraph 1 of the 1945 Constitution that the economy is structured as a joint venture, then economic actors are not only limited to BUMN, private companies, and cooperatives, but also the community, business groups, legal entities and also business entities that carry out activities in the market 
so that the principles of kinship and togetherness can be realized. The spirit of crowdfunding to help finance businesses for MSMEs and startups that do not have large capital can be said to be similar to a cooperative business form that has cooperative principles in an ideal form. In other words, any form of business as long as it has a cooperative spirit based on the principle of kinship is a form of business that is under the people's economic system.

SCF's opportunity in helping capital for MSMEs and startups can be said to have fulfilled the mandate of the economic constitution. However, several things need to be strengthened to protect investors, for example, organizers who are foreigners or foreign legal entities, the importance of supervision from the competent authorities because it involves money from the people, if the money collected in the escrow account is taken away by the organizers it will cause loss for investors. In SUKUK, if the issuer fails to pay the debt securities, who will be responsible.

With supervision from the OJK, the regulation of the practice of SCF activities will take place properly and the certainty of individual property rights in this case investors, issuers, and organizers will be guaranteed, the contracts made by the parties in the SCF will be obeyed by the parties as to the law and the community will benefit by this SCF activity, the opportunity to create jobs and improve the community's economy that is independent and not dependent on foreign capital.

\section{Conclusion}

POJK Number 57/2020 as a regulation in the SCF in the Indonesian legal system aims at protecting investors, providing access to capital for entrepreneurs who do not have large capital in developing their businesses, increasing market efficiency by providing benefits to parties in the SCF industry as well as creating fair business competition.

The concept of crowdfunding in financing MSMEs and startups that can compete in the global market with other businesses is said to be under the legal politics of Indonesian MSMEs based on Pancasila. The concept of crowdfunding when viewed from article 33 paragraph 1 of the 1945 Constitution that the economy is structured as a joint venture, then economic actors are not only limited to BUMN, private companies, and cooperatives, but also the community, business groups, legal entities and also business entities that carry out activities in the market so that the principles of kinship and togetherness can be realized

\section{References}

[1] Indonesia 2020 Dan Solusinya (online) Info Singkat, 20-21, https://berkas.dpr.go.id/puslit/files/info_singkat/Info\%20Singkat-XII-15-I-P3DI-Agustus-2020206.pdf (10 Juli 2021).

[2] Dhiany Nadya Utami, OJK Akan Revisi Aturan Equity Crowdfunding (online), https://market.bisnis.com/read/20201201/7/1324975/ojk-akan-revisi-aturan-equity-crowdfunding (1 Desember 2020).

[3] Indonesia, Otoritas Jasa Keuangan, Peraturan tentang Penawaran Efek Melalui Layanan Urun Dana Berbasis Teknologi Informasi, POJK No. 57/POJK.04/2020, LN RI Tahun 2020 Nomor 281, Tambahan LN RI Nomor 6594. Pasal 1 angka 10.

[4] Cita Yustisia Serfiyani, Karakteristik Sistem Crowdfunding Sebagai Alternatif Pendanaan Industri Kreatif, Disertasi Tidak Diterbitkan, Surabaya, Fakultas Hukum Universitas Airlangga, 2018. 
[5] Juredieu, F., \& Mayoux. (2016). Crowdfunding Legal Framework: An International Analysis. International Perspectives on Crowdfunding. emerald insight, Page 81-97.doi:10.1108/978-178560-315-020151005

[6] Stanislav Mamonov \& Ross Malaga. (2018). Success factors in Title III equity crowdfunding in the United States. (Journal Electronic Commerce Research and Applications, 27(2018), 65-73. https://doi.org/10.1016/j.elerap.2017.12.001.

[7] Maximilian Goethnera,b , Lars Hornufc,d,e , Tobias Regner (2021). Protecting investors in equity crowdfunding: An empirical analysis of the small investor protection act. Journal Technological Forecasting and Social Change, 162, 120352. doi: 10.1016/j.techfore.2020.120352.

[8] Jimly Asshiddiqie, Konstitusi Ekonomi, PT. Kompas Media Nusantara, Jakarta, 2015, hlm.347348.

[9] Kenton, Will., 2021, What Is a Security? (online), https://www.investopedia.com/terms/s/security.asp (20 Maret 2021)

[10] Peter Mahmud Marzuki, Penelitian Hukum, Kencana Prenada, Jakarta, 2010, hlm. 35.

[11] Amiruddin dan H. Zainal Asikin, Pengantar Metode Penelitian Hukum, PT. Raja Grafindo Persada, Jakarta, 2006, hlm. 118.

[12] Johnny Ibrahim, Pendekatan Ekonomi Terhadap Hukum: Teori dan Implikasi Penerapannya Dalam penegakan Hukum, CV.Putra Media Nusantara dan ITS Press Surabaya, Surabaya, 2009, hlm.5054.

[13] Ade Komarudin, Politik Hukum Integratif UMKM: Kebijakan Negara Membuat UMKM Maju dan Berdaya Saing, RMBooks, Jakarta, 2014, hlm.19-23.

[14] Paul R. Gregory and Robert C. Stuart, Comparative Economic System, Fourt Edition, Houghton Mifflin Company, Boston, page.24.

[15] Harold J. Berman, Law and Revolution, Harvard University Press, Cambridge, Massachussets, 1997, page. 245-247.

[16] Fajar Sugianto, Economic Analysis of Law: Seri Analisis Ke-ekonomian Tentang Hukum, Seri I, Pengantar, Kencana Prenadamedia Group, Jakarta, 2014, hlm. 74-75. 